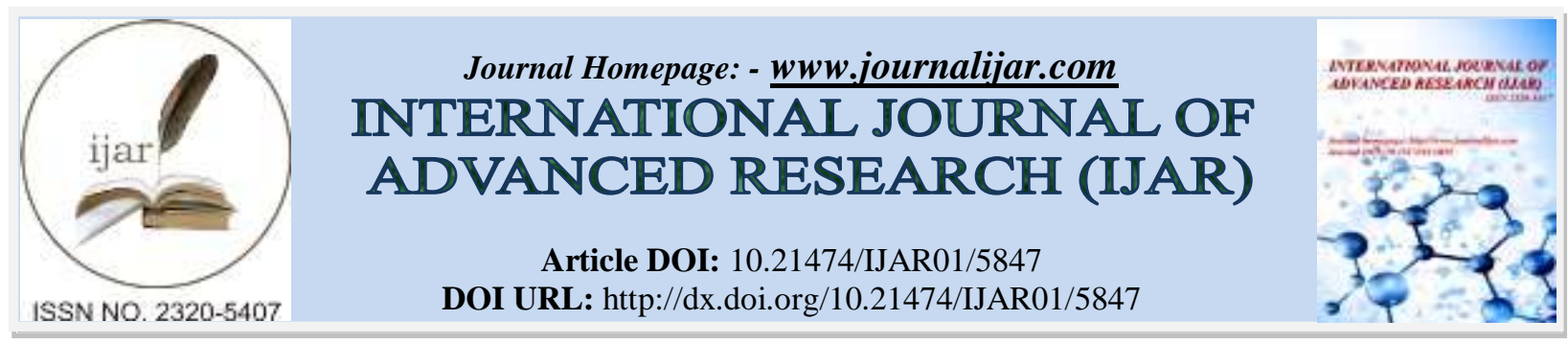

RESEARCH ARTICLE

\title{
THE PROFESSIONAL TRAINING OF STUDENTS FROM PHYSICAL EDUCATION AND SPORT. FACILITIES IN THE SPORTS FIGHTING DISCIPLINE.
}

Dr. Cristian Ştefan Liuşnea.

Associate professor Faculty of Physical Education and Sport, University „Dunărea de Jos” Galaţi, Romania.

\section{Manuscript Info}

Manuscript History

Received: 13 September 2017

Final Accepted: 15 October 2017

Published: November 2017

Key words:-

Fighting Sports, Bachelor's Degree, Training Of Students.

\section{Abstract}

In the mentality and practice of contemporary society, the idea of harmonious development and the maintenance of the state of health, which is practically reflected in an optimal physical condition, is gaining more and more ground. This is also explained by the attractiveness of some sporting disciplines such as fitness and fighting sports, the latter having a broad applicative character. Lately, they are also known as combat sports, and their sphere is gradually expanding in Romania, so the phrase includes not only traditional sports such as free wrestling, Greek-Roman fights, judo but also more exotic sports such as martial arts.

Changes in collective mentality and everyday practice are also reflected in the programs of higher education institutions that have diversified their education offer quite a bit. Analyzing this offer, we have found that most of the institutions have chosen to keep in the education plans of the wrestling, with the most often occurring disciplines such as judo. I followed the situation of the educational plans from 10 universities in the country. Five of them have plans and a course of struggles, while four of them have combat courses and judo.

Analyzing the data, I came to the conclusion that most faculties that devised study plans for the first Bologna cycle (Bachelor's degree) introduced both coursework (methodical) and Practical Works.

Copy Right, IJAR, 2017,. All rights reserved.

\section{Introduction:-}

In the mentality and practice of contemporary society, the idea of harmonious development and the maintenance of the state of health, which is practically reflected in an optimal physical condition, is gaining more and more ground. This is also explained by the attractiveness of some sporting disciplines such as fitness and fighting sports, the latter having a broad applicative character. Lately, they are also known as combat sports, and their sphere is gradually expanding in Romania, so the phrase includes not only traditional sports such as free wrestling, Greek-Roman fights, judo but also more exotic sports such as martial arts.

Changes in collective mentality and everyday practice are also reflected in the programs of higher education institutions that have diversified their education offer quite a bit. 


\section{Methods:-}

Analyzing this offer, we have found that most of the institutions have chosen to keep in the education plans of the wrestling (tab 1 and 3, fig.1), with the most often occurring disciplines such as judo (tab 2 and 4, fig. 2). I followed the situation of the educational plans from 10 universities in the country. Five of them have plans and a course of struggles, while four of them have combat courses and judo.

Analyzing the data, I came to the conclusion that most faculties that devised study plans for the first Bologna cycle (Bachelor's degree) introduced both coursework (methodical) and Practical Works.

As far as struggles are concerned, they are an ideal means of harmonious development of the human body, its practice also has an impact on the development of moral, moral, psychological qualities, such as honor, courage, daring, will, initiative. They involve the analysis of situations, the mastery of the techniques of the execution procedures, the ability to know the opponent and to adapt the tactical battle strategy in a short time, many of which are completed by prompt and efficient decisions taken in a fraction of a second, under conditions of the competition.

We must not forget that the fights are represented in the Olympic Games program, being included since their first modern edition in 1896. At the beginning of the 20th century (1908) they became Olympic sports under the two forms: free fighting, fights Greek-Roman, to which judo was added later.

According to specialists such as V. C. Dahnovschi and S. S. Lescenko (1990), today the wrestling are practiced by about 4 million people worldwide, while only in Russia, the number of practitioners reaches a million, while there are 500,000 in the US.

Table 1:- Number of hours allocated (Course / Practical works) of the sport discipline Fighting according to the curricula of the faculties of Physical Education and Sport after the implementation of the Bologna model

\begin{tabular}{|c|c|c|c|c|c|c|c|}
\hline \multirow[b]{2}{*}{ No. } & \multirow{2}{*}{$\begin{array}{l}\text { Higher education } \\
\text { institution }\end{array}$} & \multicolumn{2}{|c|}{ Year I } & \multicolumn{2}{|c|}{ Year II } & \multicolumn{2}{|c|}{ Year III } \\
\hline & & Sem I & Sem II & Sem I & Sem II & Sem I & Sem II \\
\hline 1. & FEFS Constanța & - & - & - & - & - & 1C 2PW \\
\hline 2. & FEFS Galați & - & - & - & - & $2 \mathrm{C} 2 \mathrm{PW}$ & - \\
\hline 3. & FEFS Timisoara & $2 \mathrm{PW}$ & - & - & - & - & - \\
\hline 4. & FEFS Cluj & - & - & - & - & - & $1 \mathrm{C} 2 \mathrm{PW}$ \\
\hline 5. & DEFS Târgoviște & - & - & - & - & - & $1 \mathrm{C} 2 \mathrm{PW}$ \\
\hline
\end{tabular}

Table 2:- Number of hours allocated (Practical Course / Practice) of the Judo Sports discipline according to the curricula of the Faculty of Physical Education and Sport after the implementation of the Bologna model

\begin{tabular}{|c|l|l|l|l|l|l|l|}
\hline \multirow{2}{*}{ No. } & \multicolumn{2}{|c|}{$\begin{array}{c}\text { Higher education } \\
\text { institution }\end{array}$} & \multicolumn{2}{c|}{ Year I } & \multicolumn{2}{c|}{ Year II } & \multicolumn{2}{c|}{ Year III } \\
\cline { 3 - 8 } & Sem I & Sem II & \multicolumn{1}{c|}{ Sem I } & Sem II & Sem I & Sem II \\
\hline 1. & FEFS Constanţa & - & $1 \mathrm{C} 1 \mathrm{PW}$ & - & - & - & - \\
\hline 2. & $\begin{array}{l}\text { FEFS Bucureşti } \\
\text { Ecologica }\end{array}$ & - & $1 \mathrm{C} 2 \mathrm{PW}$ & - & - & - & - \\
\hline 3. & FEFS Piteşti & - & - & $1 \mathrm{C} 1 \mathrm{PW}$ & - & - & - \\
\hline 4. & FEFS Braşov & & $1 \mathrm{C} 2 \mathrm{PW}$ & - & - & - & - \\
\hline 5. & FEFS Iaşi & - & - & - & - & $1 \mathrm{C} 1 \mathrm{PW}$ & - \\
\hline 6. & DEFS Târgovişte & - & - & - & - & - & $1 \mathrm{C} 2 \mathrm{PW}$ \\
\hline 7. & FEFS Galaţi & - & $2 \mathrm{C} 2 \mathrm{PW}$ & - & - & - & - \\
\hline 8. & FEFS Craiova & - & - & - & $2 \mathrm{C} 2 \mathrm{PW}$ & - & - \\
\hline 9. & FEFS Timişoara & $1 \mathrm{C} 1 \mathrm{PW}$ & - & - & - & - & - \\
\hline 10. & FEFS Suceava & - & - & - & $2 \mathrm{C} 2 \mathrm{PW}$ & - & - \\
\hline
\end{tabular}


Table 3:- Number of hours allocated to sports discipline Fighting according to the curricula of the Faculty of Physical Education and Sport after the implementation of the Bologna model

\begin{tabular}{|c|c|c|c|c|c|c|}
\hline \multirow{2}{*}{ No. } & $\begin{array}{c}\text { Higher education } \\
\text { institution }\end{array}$ & \multirow{2}{*}{$\begin{array}{c}\text { Total } \\
\text { number } \\
\text { hours }\end{array}$} & & $\begin{array}{c}\text { Theoretical courses } \\
\text { Number } \\
\text { hours }\end{array}$ & Percent & \multicolumn{2}{c|}{$\begin{array}{c}\text { Practical works } \\
\text { Number } \\
\text { hours }\end{array}$} & Percent \\
\hline 1. & FEFS Constanța & 42 & 14 & $33,33 \%$ & 28 & $66,66 \%$ \\
\hline 2. & FEFS Galaţi & 56 & 28 & $50 \%$ & 28 & $50 \%$ \\
\hline 3. & FEFS Timişoara & 28 & - & - & 28 & $100 \%$ \\
\hline 4. & FEFS Cluj & 42 & 14 & $33,33 \%$ & 28 & $66,66 \%$ \\
\hline 5. & FEFS Târgovişte & 42 & 14 & $33,33 \%$ & 28 & $66,66 \%$ \\
\hline \multicolumn{3}{|c|}{ Average } & & $\mathbf{2 9 , 9 9 \%}$ & & $\mathbf{6 9 , 9 9 \%}$ \\
\hline
\end{tabular}

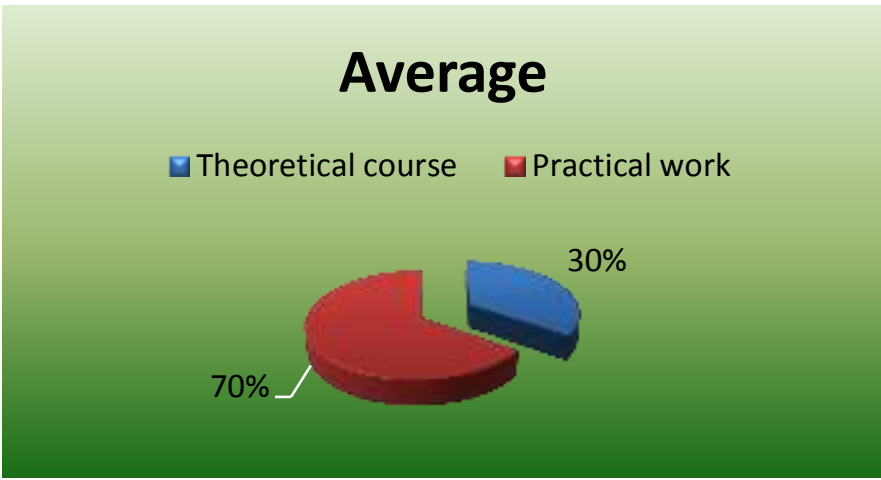

Fig. 1:- Average total number hours theoretical courses and practical works allocated to sports discipline Fighting.

Table 4:- Number of hours allocated to judo discipline according to the curricula of the Faculty of Physical Education and Sport after the implementation of the Bologna model

\begin{tabular}{|c|c|c|c|c|c|c|}
\hline \multirow[b]{2}{*}{ No. } & \multirow{2}{*}{$\begin{array}{c}\text { Higher education } \\
\text { institution }\end{array}$} & \multirow{2}{*}{$\begin{array}{c}\text { Total } \\
\text { number } \\
\text { hours }\end{array}$} & \multicolumn{2}{|c|}{ Theoretical courses } & \multicolumn{2}{|c|}{ Practical works } \\
\hline & & & $\begin{array}{c}\text { Number } \\
\text { hours }\end{array}$ & Percent & $\begin{array}{c}\text { Number } \\
\text { hours }\end{array}$ & Percent \\
\hline 1. & FEFS Constanţa & 28 & 14 & $50 \%$ & 14 & $50 \%$ \\
\hline 2. & $\begin{array}{l}\text { FEFS Bucureşti } \\
\text { Ecologica }\end{array}$ & 42 & 14 & $33,33 \%$ & 28 & $66,66 \%$ \\
\hline 3. & FEFS Pitesti & 28 & 14 & $50 \%$ & 14 & $50 \%$ \\
\hline 4. & FEFS Brassov & 42 & 14 & $33,33 \%$ & 28 & $66,66 \%$ \\
\hline 5. & FEFS Iaşi & 28 & 14 & $50 \%$ & 14 & $50 \%$ \\
\hline 6. & DEFS Târgovişte & 42 & 14 & $33,33 \%$ & 28 & $66,66 \%$ \\
\hline 7. & FEFS Galaţi & 56 & 28 & $50 \%$ & 28 & $50 \%$ \\
\hline 8. & FEFS Craiova & 56 & 28 & $50 \%$ & 28 & $50 \%$ \\
\hline 9. & FEFS Timişoara & 28 & 14 & $50 \%$ & 14 & $50 \%$ \\
\hline 10. & FEFS Suceava & 56 & 28 & $50 \%$ & 28 & $50 \%$ \\
\hline & Average & & 182 & $45 \%$ & 224 & $55 \%$ \\
\hline
\end{tabular}




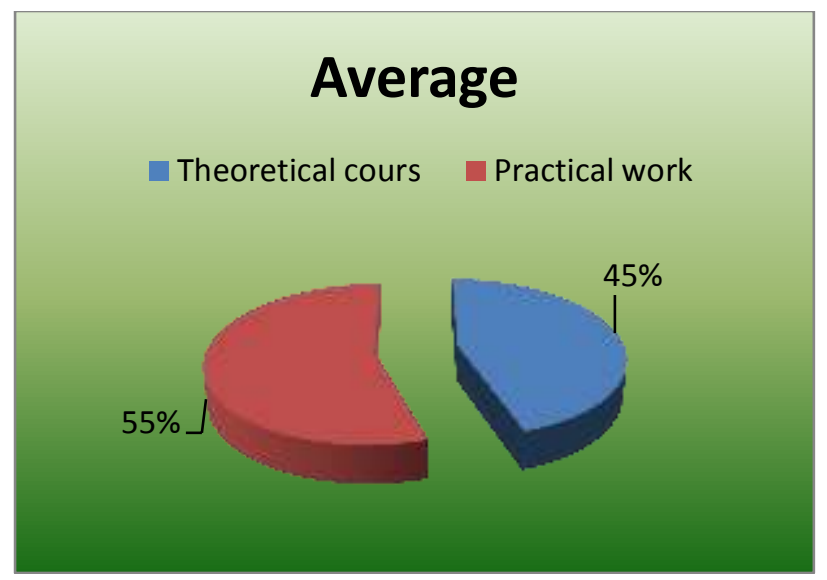

Fig. 1:- Average total number hours theoretical courses and practical works allocated to judo discipline

We have also set a certain frequency for the technical-tactical actions specific to the standing and ground combat, respectively, of all weight categories, whose dynamics we recorded in Table 5 and fig. 3.

Then, in assessing the students, we took into account the dynamics of the frequency of the technical procedures and we calculated, on the basis of the data recorded by the application of two tests one initial (the initial training level) and one final (after application of technical-tactical actions), the arithmetic mean and the deviation standard, presented in Table 6 and fig. 4.

Table 5:- Dynamics of the frequency of each technical process in all weight classes

\begin{tabular}{|c|c|c|c|c|c|c|c|c|}
\hline \multirow[b]{2}{*}{ Technical-tactical actions } & \multicolumn{8}{|c|}{ Weitht categories (kg) } \\
\hline & 54 & 58 & 63 & 69 & 76 & 85 & 97 & 130 \\
\hline $\begin{array}{c}\text { Fighting } \\
\text { 1.Hip overhang with head and arm fastening }\end{array}$ & 5 & 6 & 5 & 3 & 3,5 & 3 & 3 & 4,5 \\
\hline 2. Throwing over the hip with arm attachment & 4,5 & 6 & 2,5 & 3 & 4,5 & 3 & 4 & 2,5 \\
\hline $\begin{array}{l}\text { 3. Throwing over the hip with arm /trunk } \\
\text { attachment }\end{array}$ & 3 & 3,5 & 7 & 5,5 & 2,4 & 2 & 3 & 2,5 \\
\hline 4. Drive to the ground with backward passage & 19,5 & 18,5 & 16,5 & 14,5 & 13 & 11 & 13 & 9,5 \\
\hline $\begin{array}{l}\text { Fighting the ground } \\
\text { 5. Routing with by centering both arms }\end{array}$ & 17 & 19 & 2,2 & 17,5 & 15,5 & 13 & 10,5 & 12 \\
\hline $\begin{array}{l}\text { 6.Flipping through the centering reversed lifting } \\
\text { from the ground }\end{array}$ & 3,5 & 5 & 7,5 & 5 & 4,5 & 2,5 & 3,5 & 1,5 \\
\hline 7. Classic run and variants & 2,5 & 3 & 3 & 3 & 4 & 3 & 3,5 & 1,5 \\
\hline
\end{tabular}

Table 6:- The average and standard deviation of the technical process in all weight classes

\begin{tabular}{|c|c|c|c|c|}
\hline \multirow[t]{2}{*}{ Technical-tactical actions } & \multicolumn{2}{|c|}{$\begin{array}{c}\text { The average of technical } \\
\text { processus in all weight } \\
\text { classes (x) }\end{array}$} & \multicolumn{2}{|c|}{$\begin{array}{c}\text { Standard deviation for all } \\
\text { weight classes }(\mathrm{s})\end{array}$} \\
\hline & Initial & Final & Initial & Final \\
\hline $\begin{array}{c}\text { Fighting } \\
\text { 1.Hip overhang with head and arm fastening }\end{array}$ & 2,4 & 3,6 & 1,24 & 1,6 \\
\hline 2. Throwing over the hip with arm attachment & 2,4 & 3,1 & 1,38 & 1,42 \\
\hline $\begin{array}{l}\text { 3. Throwing over the hip with arm /trunk } \\
\text { attachment }\end{array}$ & 2,1 & 3,1 & 1,63 & 1,84 \\
\hline 4. Drive to the ground with backward passage & 11,5 & 9,5 & 4,96 & 4,24 \\
\hline $\begin{array}{l}\text { Fighting the ground } \\
\text { 5. Routing with by centering both arms }\end{array}$ & 12,3 & 10,7 & 5,24 & 4,88 \\
\hline $\begin{array}{l}\text { 6.Flipping through the centering reversed lifting } \\
\text { from the ground }\end{array}$ & 3,3 & 2,7 & 1,85 & 1,83 \\
\hline 7. Classic run and variants & 2,4 & 1,9 & 0,96 & 1,09 \\
\hline
\end{tabular}




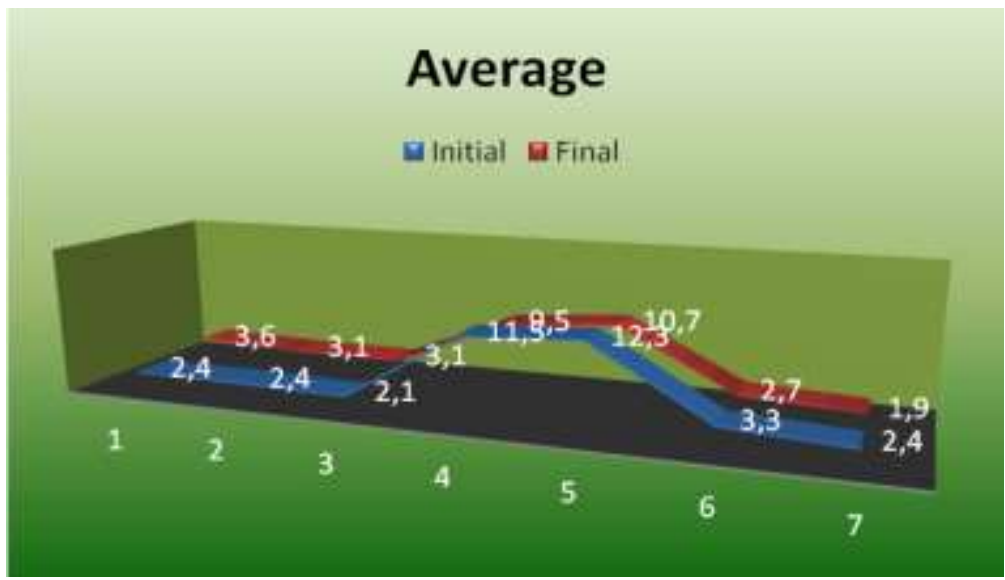

Fig. 3:- The average of technical processus in all weight classes

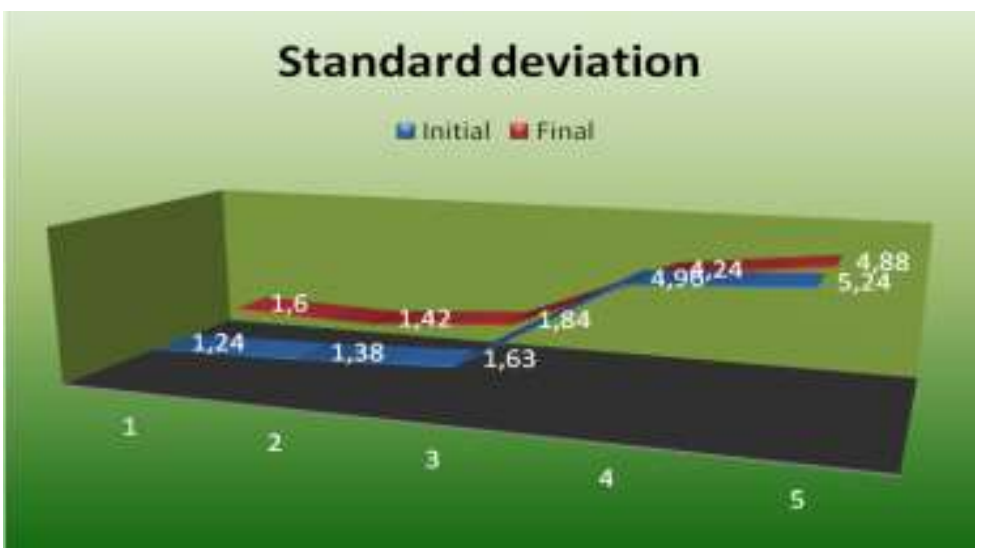

Fig. 4:- The standard deviation of technical processus in all weight classes

Analyzing the data from the 10 institutions considered, it can be observed that the percentage of classes has an average of $22,99 \%$ for combat discipline and $45 \%$ for judo, while the number of stops allocated to practical works is higher, of 69, 99\% in wrestling and 55\% in judo. In time, from 2009 to 2016, the number of these hours remained relatively constant, except for the faculty in Timişoara - West University, where the lessons have disappeared.

It can also be noted that not all universities have the same number of hours. Thus, the number of practical classes for judo is different, four (Constanţa, Piteşti, Iaşi and Timişoara) of the ten faculties opting for a reduction from two hours to one hour per week.

As far as the fixation in the curriculum is concerned, for the struggles, the authors of the curricula have opted for the third year, a faculty for the first semester and three for the last semester.

At the same time, for judo discipline, the choices of the program directors are much more varied, so five of them chose the year I, the third year II and II the third year. Of these, only three chose the semester I, and seven opted for the course to be placed in the second semester of that year. In all cases, combat and judo disciplines, respectively, practice and practice only one semester of the three years of study in the undergraduate cycle.

\section{Discussion:-}

Ioan Bontaş (2008) believes that the analytical curriculum reflects the basic content of the education for each discipline.

Any change in time, number of hours, course and/or practical work, and disposition in the first, second or third year of the discipline obliges each teacher to adapt the contents of the analytical program so that they report correctly to the level of motor training of the students, and the finality to be as close as possible to the ones proposed when it 
was drafted. As far as I am concerned, I have adapted the content of the curriculum, since the name of the discipline is the technical-tactical basis of the battles, and it is placed in the educational plan of the Faculty of Galaţi in the third year of the second semester.

\section{Conclusions:-}

The conclusions we came up with following the study are as follows:

1. Combat sports have a specific theoretical content determined by the competitive course;

2. Theoretical training allows athletes to develop the means and methods specific to fighting sports used in individual training;

3. The theoretical training tackled in tertiary courses with the content of combat sports contributes to the achievement of the objectives set in the activity with the students: training of professional and transversal competences;

4. The success of learning depends on the percentage of theoretical training in the discipline of fighting sports;

5. The discipline fights program for students must include the theoretical training content specific to combat sports, referring to framework objectives and benchmarks.

\section{Reference:-}

1. Bontaş, I. (2008) Tratat de pedagogie, Bucharest: Publisher All.

2. Cişmaş, G, Mostoflei, F. (2007) Lupte - curs de bază, Bucharest: A.N.E.F.S.

3. Dahnovschi, V.C. and Lescenko, S.S. (1990) Pregătirea sportivilor de mare performanţă. Sport de performanţă, Bucharest.

4. Liusnea, C.Şt. (2014) Bazele tehnico - tactice din lupte. Galaţi: Publisher Europlus.

5. Manolachi V. (2003) Sporturi de luptă - teorie şi practică, Chişinău: Publisher Tipografia Centrală. 